\title{
Student Reading Practices in Print and Electronic Media
}

\author{
Nancy M. Foasberg
}

This paper reports a diary-based qualitative study on college students' reading habits with regard to print and electronic media. Students used a form to record information about their reading practices for twelve days, including length of reading event, location, format used, and the purpose of reading. Students tended to use print for academic and long-form reading and to engage with it more deeply. Although electronic resources were sometimes used for academic purposes, students often used them for shorter and nonacademic reading. Students found electronic media convenient, but most of them did not wish to switch to electronic media for their academic reading.

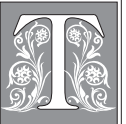

he venerable activity of reading has undergone some recent technological changes. More and more materials are available electronically, and there are often many options available for those who want to read something in an electronic format. One may read from a standard computer screen, a tablet computer, a small-form device such as a cell phone, a reading-specific digital device (an e-reader), or one may simply print out the relevant materials to read offline. Print is also an option and is still an important one for many. Although academic libraries are attempting to adjust to these new types of reading, it is not possible to adjust well without a strong understanding of students' reading practices regarding these formats.

College students' reading needs are partially created by their status as students, so their reading may differ from that of other adults. Many of their classes require significant reading, whether this is in the form of specifically assigned readings or library research. Students might also read for pleasure, for work, to become better informed, or as part of their social lives, especially if their socializing is mediated by the Internet. In each instance, readers are very likely to be confronted with a choice of formats, including those listed above.

There is some evidence that many individuals do not limit themselves solely to either print or electronic media but often use both. ${ }^{1}$ The current study seeks to understand what drives students' choices in this respect. When do students move from one format to another? Do students prefer one format for academic reading and another for leisure reading? Is there a difference between short-form reading materials, such as articles, and long-form reading materials, such as books?

Through a twelve-day diary study and two group interviews, this study seeks to explore some of these questions to provide some descriptive models of possible interactions among different formats within the lives of students.

Nancy M. Foasberg is Humanities Librarian in Benjamin S. Rosenthal Library at Queens College, CUNY; e-mail: nfoasberg@qc.cuny.edu. (C2014 Nancy M. Foasberg, Attribution-NonCommercial (http://creativecommons.org/licenses/by-nc/3.0/) CC BY-NC 


\section{Literature Review \\ Reading and Technology}

As e-books have grown in popularity, so has scholarly interest in the contrasts between electronic and printed materials. Some studies have addressed the behavior of users with electronic and print reading materials, including how electronic and print behaviors differ.

The Pew Research Institute found that, although that print is still dominant, there was a dramatic increase in e-book reading between June 2010 and December 2011. The number of respondents who had read an e-book, rather than a print book, "yesterday" rose from 4 percent of readers to 15 percent. ${ }^{2}$ However, the same study found that 88 percent of those who read e-books had read print books as well. ${ }^{3}$ On a much smaller scale, Foasberg found that, among a small sample of students who owned e-readers, only 43 percent used the device for two-thirds of their reading or more. ${ }^{4}$ These results suggest that use of electronic texts, including e-books, does not indicate that readers are forsaking other formats.

There are several reasons that readers, and students in particular, may choose one reading format over another. Readers' personal preferences may come into play when they are selecting reading formats. Shrimplin et al. found four distinct groups of readers, all of whom approached print and electronic texts in different ways: Book Lovers, who preferred print; Technophiles, who preferred electronic formats; Pragmatists, who use whatever format best suits their needs at the time; and Printers, who print out electronic texts to read them. ${ }^{5}$ Chelin et al. found that students used e-books if they were easier to access or if the print edition was not available, rather than because of any preference for them. ${ }^{6}$ Additionally, demographic characteristics may influence use of e-books. For instance, Caporn et al. found that the younger students in their study, who were between the ages of eighteen and twenty-one, were more attracted to e-books than older students were. ${ }^{7}$ Some subjects in this study felt that limited printing was one of the drawbacks of this format because they did not wish to read these materials from a computer screen. Broadhurst and Watson speculated that students will demand additional printing credits if many materials are made available electronically. ${ }^{8}$

The constraints of time and space may also play a role in format choice; Shelburne found that faculty and students appreciated computer-based e-books for the speed and convenience with which they can be accessed, but many readers prefer to print out sections rather than rely on a computer and an Internet connection for access. ${ }^{9}$ For e-books used away from the computer, however, portability is often considered a benefit. For instance, participants in Marshall and Ruotolo's study often used small reading devices while traveling or commuting, situations in which print would have been more cumbersome. ${ }^{10}$ Chelin et al. note that students may use computer-based electronic formats because of inertia,; ${ }^{11}$ since students are used to doing most of their work at the computer, it is easier for them to use texts they can access without leaving their computers. Throughout the literature, it appears that many students enjoy the convenience of accessing materials electronically, but they often print out materials to use them.

The nature of the activity in which readers are engaged is also important. There is some agreement in the literature that different reading tasks call for different practices, and different formats may do a better or worse job of supporting certain practices. Because many electronic texts feature primarily linear navigation and limited markup capabilities, some studies have found that activities that rely on annotation and nonlinear reading are considered easier when conducted in print, potentially impeding the academic use of these media. Sandberg, surveying the literature on academic reading online, notes that several studies have found that students prefer print and that the 
process of reading online is very different. ${ }^{12}$ Cull argues that individuals often read more quickly and less deeply online than they would in print. ${ }^{13}$ Berg, Hoffmann, and Dawson found that students doing a simple lookup task used more effective strategies to navigate the print encyclopedias than the electronic ones. ${ }^{14}$ Qayyum studied the way graduate students marked up scholarly articles they read and shared online; these students had little difficulty using the interface to annotate the documents, but complained that this method did not encourage critical thinking and resulted in "fragmented and disengaged reading." ${ }^{15}$ In Worden and Collinson's study, students' comments indicated that they preferred e-books for finding quotations, copying and pasting, while they preferred print for sustained reading. ${ }^{16}$

Electronic textbooks, although effective, have been unpopular. Several studies have found that grades and learning outcomes did not differ very much between students who used print and those who used e-textbooks. However, the students in these same studies expressed a preference for print, spent more time studying when they used a print format, and did not volunteer to use e-textbooks again. ${ }^{17}$ Students often print out their reading when it is in an electronic format, even if they are not willing to pay more for a print copy upfront, suggesting that they find it easier to work with paper than a screen. ${ }^{18}$ Student preferences may change in the future; Weisberg found, in a longitudinal study of business students, that students felt more positively inclined toward e-textbooks every year. ${ }^{19}$

The connection between e-books and active reading is of particular interest for this study. Adler et al. noted that electronic materials lacked support for notetaking, collaboration, or nonlinear reading, while Shelburne's participants complained that nonsequential access, particularly cross-referencing with other works or other parts of the same work, was much more difficult in an electronic format. ${ }^{20}$ Thayer et al. distinguished among three types of reading: skimming, receptive reading, and responsive reading. They found that electronic reading in the form of e-readers supported receptive reading: that is, "reading a text from beginning to end without critically appraising the ideas, taking notes, or interrupting one's train of thought." However, the readers did not support other types of reading as effectively; in particular, students had difficulty skimming and reading responsively, a process Thayer defines as "developing new knowledge or modifying existing knowledge by engaging with the ideas presented in a text." ${ }^{21}$ In a study that dealt with computers rather than e-readers, Gregory found that students often skimmed texts and printed out parts to use later but did not do much serious reading in this format. ${ }^{22}$ The types of engagement each medium affords do matter to students; Tarbaran, Kerr, and Rynerson found that students often used strategies such as underlining, highlighting, and annotating, although these practices did not always make a difference in their academic achievement. ${ }^{23}$ However, Weisberg found that students are indeed willing to use e-books; although few students in this study used electronic texts for all their reading, more than half used them for most of their reading. ${ }^{24}$

While publishers of electronic books have begun tracking differences in reading practices among different types of content, ${ }^{25}$ there is little research on the choices students make when faced with several possible formats in which to consume information. The current study considers how different media may fit into students' lives rather than imagining that they are exclusively either "analog" or "digital" consumers of information. What purpose does each format serve for students?

\section{What Students Read}

Students may read for academic, work, or personal reasons; many of the studies on college students' reading habits are focused on the divide between their personal and 
academic reading practices. Joliffe and Harl examine the assumption that most undergraduates do not spend enough time reading and are not careful readers. ${ }^{26}$ The students in their study did not spend the traditional two hours studying for every hour in class; however, they spent a good deal of time with their personal, self-chosen reading and engaged much more deeply with it, whether this involved religious reading, fantasy novels, or correspondence with friends. Mokhtari, Reichard, and Gardner found that students reported spending more time on academic reading than on leisure reading or watching television, although they reported enjoying academic reading much less any other activity. ${ }^{27}$ In contrast, students rated leisure reading as an enjoyable activity, but they did not devote much time to it. Gilbert and Fister found that most students in their study enjoyed leisure reading but that they were unable to spend time on it because of the amount of time they must spend on their academic reading. ${ }^{28}$ Huang found that students spent more time reading messages on social media sites on the Internet than they did reading academic or extracurricular materials; the students in this study often avoided reading textbooks if possible. ${ }^{29}$ Parlette and Howard point out that, for some students who are deeply engaged with their studies, the distinction between academic and pleasure reading may be more difficult to make. ${ }^{30}$

However, the studies of academic and leisure reading discussed above give little attention to students' choice of format, leaving open the question of whether they are more likely to choose different media for different types of reading.

\section{Methodology}

The current study attempts to capture students' reading over the course of two school weeks and one weekend to get a more detailed and accurate picture of students' reading practices as a whole and to better understand how different formats fit into students' reading lives. Because this study attempts to describe accurately the day-to-day practices of a small number of students, the diary method was chosen. Diary studies require subjects to record their behavior during the course of the study. This produces more accurate data than traditional surveys, because it does not rely on subjects' recall or general impressions of activities in which they may have engaged days or weeks earlier.

Diary methods have often been used in studies of reading and writing activities of both general adult populations and students. ${ }^{31}$ Of particular interest to the present study is Joliffe and Harl's use of diaries to better understand students' engagement with academic and leisure reading texts. ${ }^{32}$ Diary methods are also a common tool for studying the question of reading and technology specifically, including Tashman and Edwards's work on active reading and the study from Thayer et al. on what kinds of reading students could best do with e-reader devices. ${ }^{33}$ Mokhtari et al. used diaries to examine how students split up their time among academic reading, leisure reading, television, and Internet use, while Huang revisited this question with a larger sample size and greater awareness of social media. ${ }^{34}$ Because reading and writing are everyday activities in which individuals engage on a regular basis, a diary study can be a very effective way to capture patterns that may not be obvious to the participants. A diary study can provide a more specific look at the way students integrate different reading formats into their lives than can a more traditional survey instrument; thus, it was chosen for this research.

During the study period, the participants were provided with a diary form that they used to record every reading activity in which they engaged for more than 10 minutes at a time, in any format. These parameters were set to include pleasure reading and social interactions that take place in writing, as well as academic reading, but to exclude incidental reading such as grocery lists, road signs, and so forth. For each entry, participants provided information about their reading, including genre, their 
location, the purpose for which they read, and the amount of time spent, as well as information about the formats with which they read, including computer screens, ereaders, print books, printouts, or mobile devices. To improve compliance, this form was provided to students in an electronic format. The first meeting with the students included training in the use of the diary form.

The study period consisted of twelve days near the middle of the fall 2012 semester. Because students' reading patterns may vary throughout the semester, the study attempted to capture a time period during which the semester was well underway but before the busy time of midterms. Part of the study coincided with religious holidays, which affected the school schedule and were observed by some of the participants. However, because the study period covered two school weeks and one weekend, it also captured a more typical week. At the participants' request, reminder e-mails were sent each day during the study period to remind them to record their reading.

To provide context for the diary data, the researcher interviewed students in small groups just before the diary-keeping period began and again after it ended. This small group format created an opportunity for discussion around the questions asked. In the first interview, information was gathered about students' typical reading patterns, the electronic devices available to them, and other demographic data such as their majors. In the exit interview, participants were asked about the experience of keeping a diary and their practices during the study. In particular, they were asked to report anything that may have made the study period unusual for them. While focus groups were used for the earlier interviews to allow participants to respond to ideas within a discussion, the researcher had to schedule some of the exit interviews individually because of students' scheduling constraints. The exit interviews were of great importance because they provided an opportunity to catch potential flaws in the data and to put the diaries into context. Both entry and exit interviews were recorded and transcribed using the Dictapad and Evernote apps on an iPad. Throughout the paper, all quotations from students come from the interviews, while the data are from their diaries.

Of the nineteen students who were originally recruited for the study, two did not produce usable data. The remaining seventeen faithfully recorded their reading throughout the study period. Although the study attempted to reduce the role of memory by asking students to track each reading event as soon as possible after it happened, participant compliance was not perfect. Some indicated during interviews that they usually submitted entries at the end of the day, sometimes keeping private records throughout the day to help them remember. Thus, the diaries are not a perfect record of student reading, but they capture day-to-day activity much better than a survey asking about students' general impression of their reading activity would.

Defining reading proved even more difficult than originally anticipated. There was some confusion among the participants as to what qualified as a reading session that they should record; they had been instructed to record every instance of reading that exceeded 10 minutes, but a few students mentioned in the exit interviews that they had not considered quick Internet reads as part of the study or that they lumped together separate reading events that concerned the same material. For future studies, it is advisable to be more explicit about the value of these types of data. There were also marginal cases whose status as reading was ambiguous, such as reading sheet music or the use of a prayer book as a memory aid (rather than as focused reading material). These ambiguities illustrate the difficulty of defining reading.

Studies that attempt to capture real-life behavior cannot control compliance and inevitably must suffer from some of these issues. Nevertheless, the student participants provided a good deal of useful data, making 288 usable entries during the two weeks that the study ran. 


\section{Subjects}

The study took place at Queens College, CUNY. Queens College is a large, diverse public college in New York City and is part of the City University of New York. Because diary studies are labor intensive for the participants, a very small group of interested students was used. After the researcher secured IRB approval, nineteen students were recruited to participate. Participants were paid fifty dollars each for their participation. Funding for subject payment was partially provided by a PSC-CUNY grant, jointly funded through The Professional Staff Congress and the City University of New York. Departmental funding provided the balance of the payments. Because this is a selfselected qualitative study, the results are not intended to be generalizable, but they can show how some students integrate different reading technologies into their lives.

Because of the labor-intensive nature of diary-keeping, the researcher wished to recruit only students who were interested in the study to reduce the number of dropouts. Furthermore, it was considered desirable to include students from as many disciplines as possible because the types of reading in which students engage may differ from one field to another. It is also possible that the culture of some majors may encourage students to use technology more than others.

Potential study participants were referred by faculty members on a campus listserv maintained by the college's Center for Teaching and Learning. This method of recruiting students ensured that the most engaged students would learn about the study and could participate, but it also tended to recruit more students majoring in departments whose faculty were members of this listserv. Because of these factors, the students do not represent a statistically representative sample of the college's population. In particular, perhaps because the listserv's administrator is a faculty member in the Language and Communication Disorders department, a disproportionate number of students were recruited from that major. Women were also noticeably overrepresented in the study; only three of the seventeen participants were male while fourteen were female. These two factors may be related, since, according to the college's Office of Institutional Research, 82 percent of majors in the Language and Communication Disorders department are women. However, a wide range of fields was represented by at least one participant in the study. Students ranged in

\begin{tabular}{|l|c|}
\hline \multicolumn{2}{|c|}{ TABLE 1 } \\
\hline Departmental Majors \\
\hline Anthropology/Area Studies & Students \\
\hline Art & 1 \\
\hline Biology & 1 \\
\hline $\begin{array}{l}\text { European Languages and } \\
\text { Literatures }\end{array}$ & 1 \\
\hline English & 2 \\
\hline $\begin{array}{l}\text { Language and Communication } \\
\text { Disorders }\end{array}$ & 7 \\
\hline Political Science & 1 \\
\hline Psychology & 2 \\
\hline Undeclared & 1 \\
\hline $\begin{array}{l}\text { NOTE: Due to double majors, the total is } \\
\text { greater than seventeen. }\end{array}$ \\
\hline
\end{tabular}
age from 18 to 32 and included upper-level undergraduates, lower-level undergraduates, and graduate students. Table 1 lists the number of students from each department who participated in the study.

Students' ages and years in college may also affect their reading practices. As table 2 shows, most of the participants in the study were juniors, seniors, or graduate students. This may be another artifact of the recruitment process if faculty members promoted the study more heavily to their upper-division classes; upperclassmen may also be more likely to participate in studies. The practices of students earlier in their college careers may be different. Since age can affect technology adoption, information about the students' ages was also gathered. All but two of the students were under the age of 25 , and a majority of the participants were 21 years old or younger. 
Student Reading Practices in Print and Electronic Media 711

\begin{tabular}{|l|c|}
\hline \multicolumn{2}{|c|}{ TABLE 2 } \\
Participants' Class Standing \\
\hline Class Standing & Students \\
\hline Freshman & 2 \\
\hline Sophomore & 0 \\
\hline Junior & 5 \\
\hline Senior & 8 \\
\hline Graduate & 2 \\
\hline
\end{tabular}

\begin{tabular}{|l|c|}
\hline \multicolumn{2}{|c|}{$\begin{array}{c}\text { TABLE 3 } \\
\text { Age of Participants }\end{array}$} \\
\hline Age (in Years) & Students \\
\hline $18-20$ & 5 \\
\hline 21 & 6 \\
\hline $22-25$ & 4 \\
\hline Older than 25 & 2 \\
\hline
\end{tabular}

These proportions are not representative of the population at the college. The students involved may be different from other students enrolled at this college in other important ways. Because this is a small group of students, they cannot be expected to represent the typical student; but, because participants vary in age, have a variety of different majors, and have different perspectives and reading habits, the results of this study can reveal some of the tendencies of students.

\section{Results and Discussion}

For students, course-related reading was paramount and usually took place in a print format. Students often engaged in responsive reading when they were reading for classes, both in print and electronic formats. However, they usually chose print when reading for class. They also engaged in electronic reading, but electronic formats were more often used for nonacademic readings, especially short articles.

\section{Student Reading: Purpose and Genre}

As the literature review noted, students engage in many different types of reading, both academic and nonacademic. Because one of the aims of the study is to understand how reading goals and reading formats overlap, the diary captured data about the materials students were reading. In the diary form, these data were gathered in free text; the form included a blank field in which students were to supply descriptive terms about their reading. Because it was not possible to specify in advance what types of reading were important to students, the data relied on students providing the information themselves. To create data that could be compared across students, the research grouped these student responses into several categories: Academic articles,

\begin{tabular}{|c|c|c|}
\hline \multicolumn{3}{|c|}{$\begin{array}{c}\text { TABLE } 4 \\
\text { Genres Read }\end{array}$} \\
\hline Genre Read & Recorded Readings & $\begin{array}{c}\text { Number of Different } \\
\text { Students }\end{array}$ \\
\hline Academic Article & 41 & 13 \\
\hline Fiction & 69 & 13 \\
\hline Miscellaneous Book & 12 & 7 \\
\hline Miscellaneous Short Reading & 9 & 5 \\
\hline Nonacademic Article & 66 & 15 \\
\hline Religious & 8 & 4 \\
\hline Textbook & 82 & 14 \\
\hline
\end{tabular}




\begin{tabular}{|l|c|}
\hline \multicolumn{2}{|c|}{ TABLE 5 } \\
Average Reading Time by Genre \\
\hline Genre & $\begin{array}{c}\text { Mean Reading } \\
\text { Time (Minutes) }\end{array}$ \\
\hline Academic Article & 55 \\
\hline Fiction & 69 \\
\hline Miscellaneous Book & 63 \\
\hline Miscellaneous Short Reading & 45 \\
\hline Nonacademic Article & 42 \\
\hline Religious & 108 \\
\hline Textbook & 91 \\
\hline
\end{tabular}

nonacademic articles, fiction (including works identified as novels, short stories, and poetry), religious reading, and textbooks. Students also read other types of books, including how-to materials; these were classified as "miscellaneous books." Finally, shorter materials such as class notes or study guides fall into the category of "miscellaneous short reading." Note that the value of these categories depends on students' descriptions of their reading; the study did not ask them to mention particular titles. Students tended to refer to shorter readings generally as "articles," not distinguishing among blog posts, online news articles, scholarly journal articles, and so forth. For the purposes of this study, articles read for a class or explicitly identified as academic journal articles were considered "academic," while all other articles and blogs were considered "nonacademic." This was an interesting distinction to make for the purposes of data analysis because it revealed some interesting tendencies with regard to medium, reading time, and engagement with the reading.

Consistent with both their own impressions and with other research findings, ${ }^{35}$ students spent much more time reading for their classes than for other reasons. They logged 162 entries reporting reading related to a specific course and 125 entries not related to a course. Reading sessions involving academic materials were longer on average: 75 minutes, compared to 56 minutes for the nonacademic reading. While classes are in session, reading for class takes up a good deal of students' time.

Figure 1 shows which genres students read for class and for other reasons. Textbooks comprised the largest group of course-related reading entries, but fiction and articles

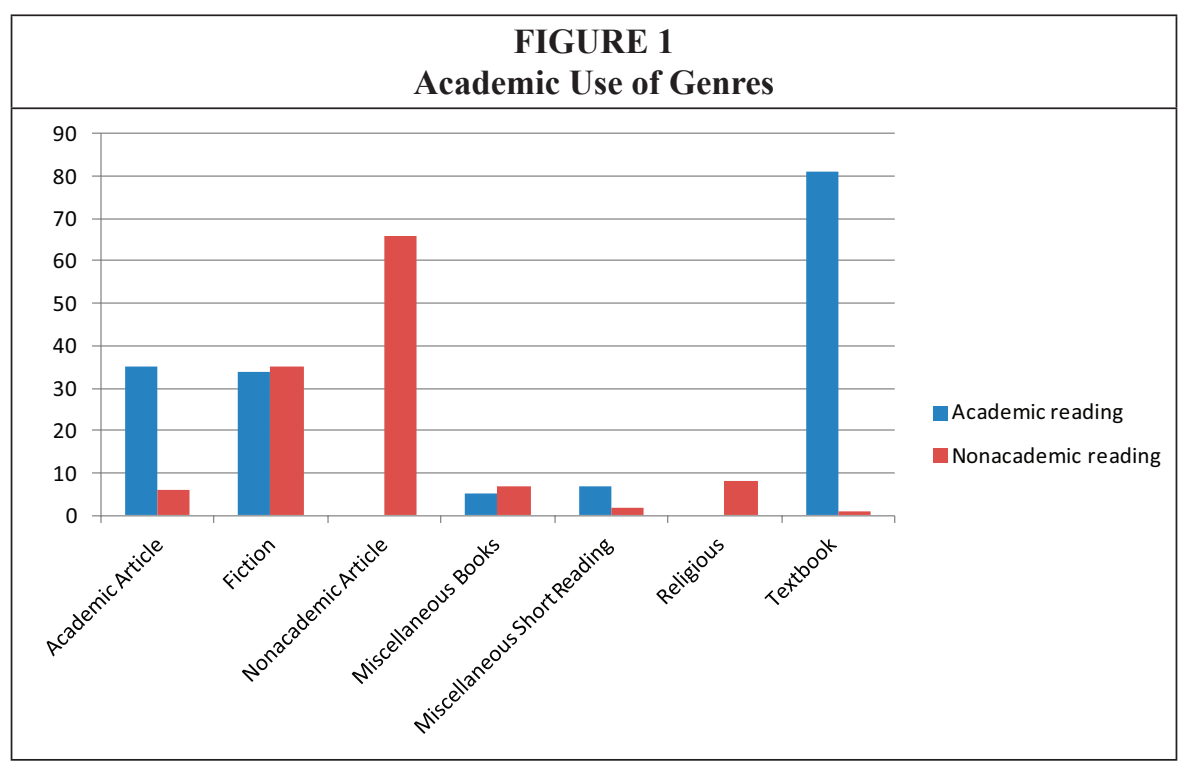


are also frequently identified as class readings. Participants' reading outside of class consisted largely of nonacademic articles. These were brief, with an average session length shorter than any other genre, and tended to be read online. Fiction, too, made up a large proportion of students' leisure reading; that was mostly read in print.

In the interviews, several students discussed the ways that their reading habits during the school year were different from their habits during breaks. Several of them mentioned that they did not have as much time for what they called "personal reading" during the semester, because class readings consumed so much of their time. One student described her attempts to continue her recreational reading during the school year:

I read personally a lot. Like, I think over the summer I maybe read two or three novels a week. I don't watch TV, so when I'm home, I'm in my room reading. So, I do that, and during the semester, if I'm reading, it's textbooks or school stuff, but I still try to read at least one book, for me, a week.

A few expressed frustration at their inability to fit recreational reading into their schedule:

I need to give myself more space to read stuff that I just enjoy reading. I noticed that I hadn't done that in a loooong time. It's all about school. Just-like the time I have, I can't devote it to read anything else that is not for school... It was just all books, and thick books. Textbooks. Yeah. So that was a little too boring.

Thus, students have rather specialized reading needs because they need to read for their classes. Their reading life as students differs from the one that they live when they are not enrolled in school. Because of these practices, college students are distinct from the general population in terms of their reading, and their needs should be considered separately. The next section considers the practices that students actually enact, especially with regard to format, to better consider what these needs are.

\section{Student Reading: Practices and Engagement}

For the participants in this study, academic reading is a very different mental and physical experience from other kinds of reading. When asked about the difference that purpose makes in their reading practices, the participants cited differences in their physical posture, their engagement with the text, and the genres they found themselves reading. These differences indicated that most participants believed they were more likely to engage in responsive reading when they were reading for school; that is, they engaged with the text to integrate it with what they already knew, rather than more passively receiving the information (receptive reading). One sign of responsive reading is responding to the text by annotating, highlighting, and taking notes. Although one student, a speed reader, indicated that he reads less closely when reading for school, most students reported the opposite:

- I know I find myself physically hunched over like a paper, clawing away at it with my pen, you know, rereading it over and over (mimes leaning over a table, pen in hand), as opposed to, let's say I'm reading a novel or something, you know, it's much more laid back (leans back comfortably), and as you read I feel like I could let my imagination just completely fill in the characters.

- When it's articles or even novels, I take my pen out. I don't like highlighters. I take my pen out and I start taking notes, just so when I go back or I have to write a paper, I can remember, where, you know, points are made and such. But if it's for fun, I definitely don't take notes or anything. I feel like it's my break. 
Supporting the idea that these behaviors help them to read responsively and are useful for academic reading, students indicated that they find the process of annotating texts helps them to absorb information:

- I'm writing notes for a class or a test, once I write the notes, I don't actually need to study from them, 'cause once I've written them, that's how I learn it. It's the same thing for textbooks, like if I'm writing the notes on the side, that's how I remember what it is.

The diaries reflected the same behavior described above; participants were much more likely to take notes or mark up their reading when it was for class. Table 6 shows how students engaged with texts for course-related and other reading. Out of the 162 readings designated "for class," 102 of them, or 64 percent, involved marking up the reading, taking notes separate from the reading, or both. These strategies of engaging with a text were almost entirely absent in the readings that were not for class; they were only used in five reading sessions out of 125 . Note that nonacademic reading often involved different signs of engagement, however; students sometimes shared their reading with another person or followed links or citations.

\begin{tabular}{|l|c|c|}
\hline \multicolumn{3}{|c|}{ TABLE 6 } \\
Engagement with Texts (Choose as Many as Desired) \\
\hline Reading Strategy & & Nonacademic Reading \\
\hline & Academic Reading & 93 \\
\hline Only Read & 51 & 17 \\
\hline Shared with Someone & 11 & 3 \\
\hline Took Notes Separately & 75 & 2 \\
\hline Marked Up the Reading & 64 & 12 \\
\hline Followed Links or Citations & 6 & 0 \\
\hline Used a Reference Work & 11 & . \\
\hline
\end{tabular}

In this study, signs of engagement were the most important means of signaling whether students were reading responsively. Other practices may be important to academic reading, including skimming to get an idea of the content, scanning for a specific piece of information, and moving nonsequentially among different sections of the material. Students were asked to include this information in the diary form, but students were most likely to say that they read carefully and sequentially, whether they were reading for a class or not. They were more likely to skim only when reading on a computer or with a mobile device. In the vocabulary used by Thayer et al., ${ }^{36}$ careful, sequential reading could signal either receptive or responsive reading; however, the greater prevalence of note-taking for class readings compared to other materials suggests that students were more likely to read them responsively.

\section{Student Reading: Engagement and Format}

One of the primary research questions for the study was whether students' selection of a print or electronic format for their reading was influenced by whether the reading was related to school. From the diary results, it is clear that it does make a difference whether students are reading for class. Figure 2 shows the use of each reading format for academic and nonacademic reading. Each format had a strong slant in one direction or the other. Dedicated e-book readers, mobile devices, and tablet computers were almost exclusively used for nonacademic reading. Paper printouts were nearly always 
used for academic reading. Even (desktop or laptop) computers and print books, which showed a more even split, tilted heavily one way or the other; 60 percent of the participants' reading with a computer was not for class, while 66 percent of their reading with print books was. Print magazines and newspapers were recorded as print books, which may affect participants' engagement with them.

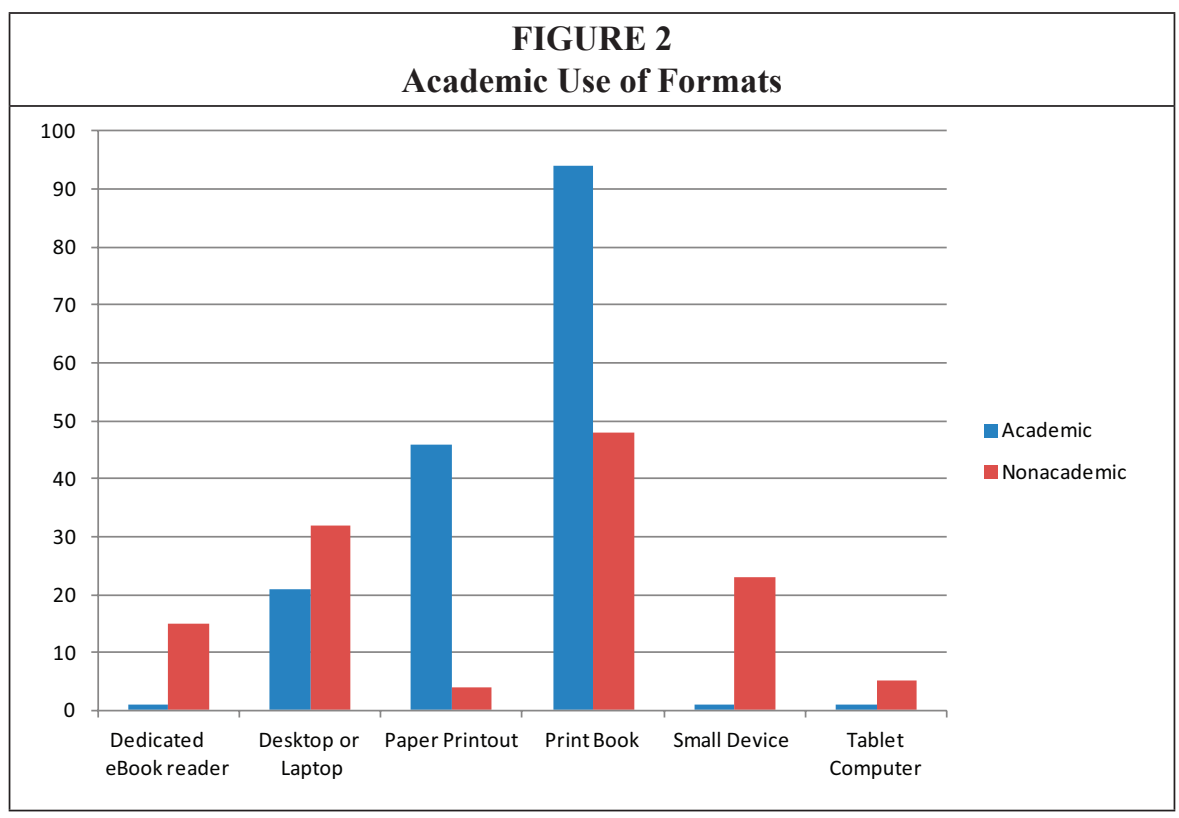

Books and paper printouts, the two formats that were used primarily for course readings, were both print formats. While there is clearly a difference between books originally published in print and material printed out after being first accessed online, they are similar in the types of engagement that they allow the reader. As we have seen, students are more likely to engage with readings through annotation or note-taking when they are reading for their classes; thus, if students tend to use print formats for their course readings, it is not surprising that these same signs of engagement also more prevalent in those formats. Because format choice, annotation practices, and the purpose of the reading all overlap, it is not clear whether students choose print for course readings because it is easier for them to annotate or whether they are more likely to annotate print materials because these are the materials they are reading for their courses. Regardless of the cause, however, students were more likely to engage in the practices described above as typical of responsive reading when they were reading in print. Students took notes or annotated their reading in 42 percent of sessions with nonelectronic formats (92 out of 189), while participants only engaged in these practices for 16 percent of sessions involving electronic formats (16 out of 98). Figure 3 provides more details about the variations among different formats and different types of engagement.

Comments from the focus groups indicate that at least some of the students use print for course-related readings due to preference, especially when these readings were textbooks. Throughout the study, no textbook was used in an electronic format, although the campus bookstore does offer some electronic textbooks. In the early focus groups, several participants explained that they had experimented with e-textbooks in the past 


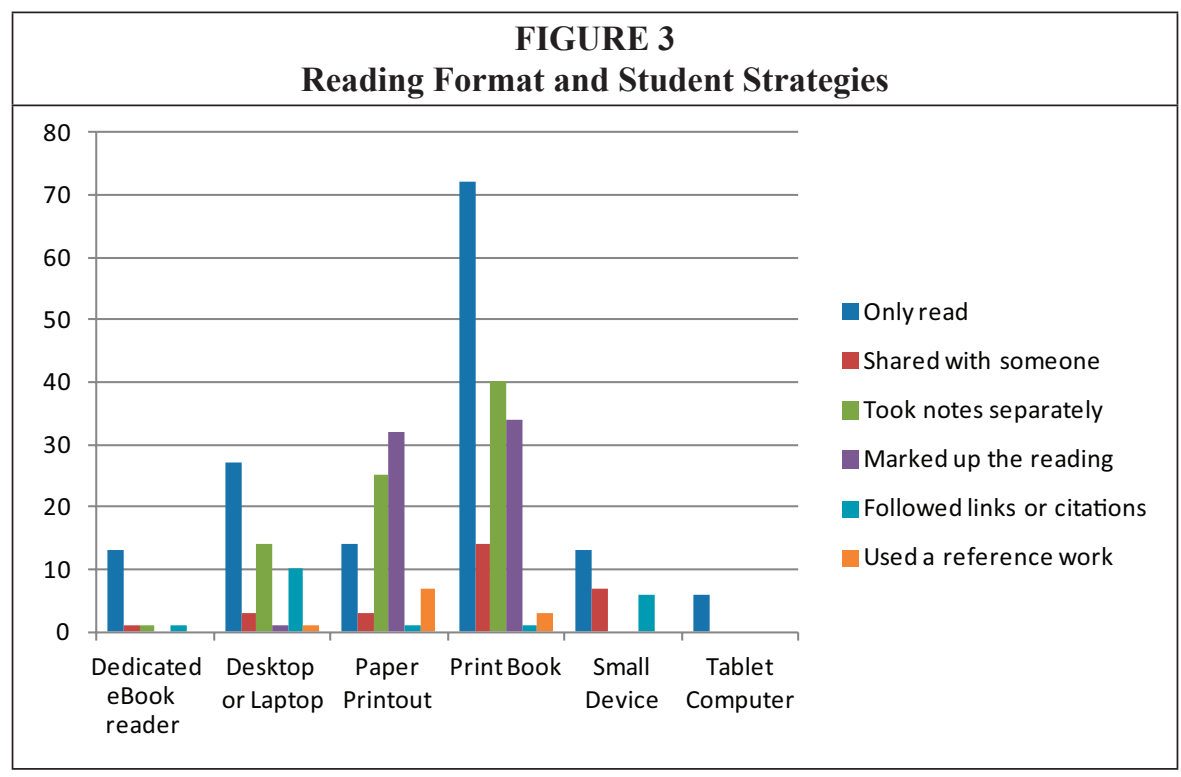

but did not intend to use them again. Some participants explained that they had more difficulty focusing on electronic texts and were frustrated that they could not interact with them in the same ways that they were used to interacting with printed textbooks:

- Last semester for one of my classes, I had the option of buying my textbook with the online version, and it was like a quarter of the price, so I did it, but I find that, like, I need the actual print of the textbook, so I concentrate.

- This was my first semester where almost every class has a book. And you'd think that would be crazy expensive, but sometimes I think to myself, if I can't read on the computer, I'm going to print all this stuff. It's going to cost the same amount.

At least one student mentioned that he felt comfortable with online textbooks, but he did not use any during the course of the study. For these students, electronic textbooks were not a good option. Some of the textbook readings were identified as printouts, which may mean that students were using electronic textbooks but printed them out to read; as the student above points out, however, this reduces or eliminates the benefit of electronic textbooks' lower prices.

However, the study participants do not completely eschew electronic resources for their schoolwork, nor do they avoid responsive reading when they do. Electronic formats were used for school readings 21 times, and participants reported taking notes or annotating their reading 12 of those times. One student described her practice of copying and pasting relevant materials from her reading into an open word processing document on her computer, so that she could later use them in papers. This is one way to take notes in another document, but she was far from the only student to use such a strategy. Over the course of the study, nine of the seventeen participants said that they had taken notes separate from the original document while using a desktop or laptop computer to read. For the most part, these were articles for class, although students also recorded reading a photography book and a novel this way. These practices were not much discussed in the focus groups, but they suggest an interesting topic for future research. The participants were capable of engaging in responsive reading when using a computer. However, the use of paper printouts for course-related reading far outnumbered the use of desktop or laptop computers for that purpose. It is also notable 
that participants used a computer rather than another electronic device for fifteen of the sixteen sessions in which they marked up or took notes on class materials; note-taking with portable devices was not popular with this group of students.

Nevertheless, students did find some benefits in studying electronically. They were especially fond of the search functions that many electronic formats provide. The forms of engagement that were common with electronic formats were following links and sharing with others. Following links in particular was valuable to students when they were using electronic formats; despite the smaller number of electronic readings that were recorded in the study, most of the instances in which participants recorded following a link or a citation, it was in an electronic format. This is an advantage of working electronically, but participants also found it distracting at times:

- The only thing that I like about it [reading electronically] is that when you're connected to the Internet, and you find out a word you don't know, you can just click here and have the definition.... Which sometimes can be a distraction!

- It's like you're reading it and the little hand's in the air. "You must click on me! And I can take you elsewhere!" and then, that other place is, oh! Something interesting, and it takes you to a third place. By the time you realize, it's time to go to class and you didn't do the actual reading.

In the interviews, some students suggested that their preference for print may be a function of their age. They saw themselves as the generation prior to the one in which electronic reading will become commonplace. When asked about their use of technology for reading in the interviews, the students seemed to feel that they were in the midst of a change and described the ways in which they had begun to adopt new uses of technology or think about doing so.

- We're just so used to reading on paper, that it's only recent that so much of the technology has come out on iPads and stuff...in later generations, maybe they'll be more used to iPads and stuff and reading on there, but we're just how we were grown up, you know?

- I'm twenty-one, but when I was younger, like when I was in high school, and they first started coming out with like tablets and like that. Everybody was still using textbooks, and it was only when I got to college that it started to change more and more.

- I don't know how to really put it, but print is how writing is supposed to be... Um, but then if I had an iPad, it might be different.

Student practices and preferences are not static, but they have not changed as quickly as reading technology has.

\section{Student Reading: Nonacademic Reading}

Although they complained that they could not spend as much time reading for nonacademic purposes as they would like, students did engage in nonacademic reading over the course of the study in both print and electronic formats. Tables 7 and 8 show the students' nonacademic reading in print and electronic formats. For nonacademic reading, the balance tipped in favor of electronic formats; 59 percent of the readings that were not for a class were read from a screen, while 41 percent were in paper formats including books, magazines, and paper printouts. Fiction and nonacademic articles predominated, constituting 79 percent of all reading not for class. In print, the nonacademic articles tended to come from magazines, while most of the electronic materials were short online readings that students accessed with either a computer or a cell phone.

Participants explained that, when they read online, they were much more comfortable reading short articles rather than longer materials: 


\begin{tabular}{|l|c|}
\hline \multicolumn{2}{|c|}{ TABLE 7 } \\
Nonacademic Readings in Print and \\
Printed Formats \\
\hline Type of Reading & $\begin{array}{c}\text { Sessions } \\
\text { Recorded }\end{array}$ \\
\hline Academic Article & 3 \\
\hline Fiction & 21 \\
\hline Magazines & 13 \\
\hline Miscellaneous Book & 3 \\
\hline Miscellaneous Short Reading & 1 \\
\hline Religious Reading & 8 \\
\hline Textbook & 1 \\
\hline Total & 51 \\
\hline
\end{tabular}

\begin{tabular}{|l|c|}
\hline \multicolumn{2}{|c|}{$\begin{array}{c}\text { TABLE 8 } \\
\text { Nonacademic Readings in } \\
\text { Electronic Formats }\end{array}$} \\
\hline Type of Reading & $\begin{array}{c}\text { Sessions } \\
\text { Recorded }\end{array}$ \\
\hline Academic Article & 3 \\
\hline Fiction & 14 \\
\hline Miscellaneous Book & 4 \\
\hline Miscellaneous Short Reading & 1 \\
\hline Nonacademic Articles & 52 \\
\hline Total & 74 \\
\hline
\end{tabular}

- I like to read MSN articles online because they are generally pretty short. Like, I like to read things that are pretty short online, but if it's something that's longer and harder to read, I like it in print format.

- I do read stuff online, but it's not for ten minutes. Like it's like maybe like an article or two. I read stuff all the time online, but it's not for a long time. You know, it's more like, it takes like two minutes to read an article.... If I have to do something for class, I'll print it out. I don't like to read online, very long things, you know?

The second quotation is from a student who had recorded no electronic reading. For the most part, students' behavior bore out their assertions. Most of the materials accessed electronically were short and were not for class. Of the 74 electronic articles that were read for nonacademic reasons, 52 were nonacademic articles, described by students as articles, Internet articles, or blog posts, or sometimes more specifically by subject ("fashion articles," "humor articles"). This pattern was especially strong for desktop and laptop computers; 27 of the 32 nonacademic sessions recorded with them were for these materials. Students logged 13 sessions of analogous materials in print, but they were more likely to use print to read fiction. Reading fiction electronically was very rare, except with dedicated e-book readers.

Dedicated e-book readers were used by only two of the participants. A third participant discussed her use of e-readers in the focus group, but she did not use her device during the study. For the students who used them, e-readers closely paralleled the ways that other students used print books for leisure. Students recorded reading fiction for nonacademic purposes on 35 occasions. A total of 21 were with print books, and 12 were with dedicated e-book readers. The e-book readers were overwhelmingly used for fiction, although there were some exceptions: two howto books and one blog. Nearly all the reading events that took place with e-book readers were careful, sequential reading, and very few of them involved note-taking or sharing. For other students, print leisure reading showed very similar characteristics; they tended to read it sequentially but without taking notes. This suggests that both types of reading are essentially receptive. Strikingly, the two students who used e-book readers did not use print for any of their long-form leisure reading. For them, dedicated e-book readers seemed to replace print for the specific purpose of reading fiction for leisure. However, these students continued to use print for their academic reading. 
In general, then, while some electronic formats were certainly used for academic readings, students used it more often for reading that was unconnected to class, especially for short readings. They tended to read print materials for their classes and to engage with them more responsively, while they used computers and smaller devices for quick recreational reads and to follow links or share with others. In fact, this kind of reading may be more prevalent than the results suggest because students were only asked to record reading events of ten minutes or longer, and, as one of the participants indicated above, not all reading of this type met that threshold.

\section{Conclusions}

Despite the ever-increasing popularity of new ways of reading, the study participants read in a fairly traditional way. Most of them preferred to use print for long-form and academic reading, at least partly because they felt more comfortable annotating documents in a print environment. They read electronically a great deal, but this reading consisted primarily of brief, nonacademic materials.

Their dislike of electronic textbooks was especially striking. Politicians and administrators at educational institutions have been attempting to extend the use of e-textbooks, largely for economic reasons. Most notably, Arne Duncan, the U.S. Secretary of Education, hopes that all students will be using digital textbooks by $2017 \cdot{ }^{37}$ Other high-profile figures have also shown support for electronic textbooks. ${ }^{38}$ More daringly, some faculty and universities have begun experimenting with "open educational resources": textbooks and other types of educational materials that are made freely available over the Internet. Temple University, the University of Massachusetts at Amherst, and states (including Washington and California) have launched such projects. ${ }^{39}$ The University of Minnesota provides a Open Textbook Catalog, which identifies open textbooks and allows reviews; notably, the designers of the catalog offer inexpensive print on demand options for each work, acknowledging that many students dislike online textbooks. ${ }^{40}$ In the midst of this attention to the digital, it is worth noting that students in the present study were less comfortable using textbooks in an electronic format, and some of them said they usually print out the sections they use, thus negating any savings from using a commercial electronic version of the textbooks.

The study participants understand that they are in the midst of a changing electronic environment, and they are interested in new technologies. Several of the students shared stories about discovering new ways of reading with electronic devices. They highly value the convenience of being able to access information from home. However, the students I talked to also value print for both reading fiction and for serious study. Leisure reading was very different. Much of students' leisure reading consisted of short articles on the Internet with both stationary and mobile devices. The students who used dedicated e-readers often used them for leisure reading, but they seldom did for school.

For the study participants, there are still serious barriers to the adoption of electronic reading, especially for academic purposes. Although they appreciate the convenience of accessing materials from home, much of their academic reading takes place in a print format for reasons that they have considered and can articulate. Some students were also concerned with the price of electronic gadgets. This is an important consideration for public institutions like the one where this study was conducted, because such institutions serve students who are not affluent. Publishers, administrators, and instructors would do well to consider students' preferences when making decisions about the formats in which assigned materials are made available.

\section{Future Research}

A large-scale study run along similar principles would be expensive and labor-inten- 
sive, but it could reveal whether the tendencies of these students are widespread or unusual. Failing that, it would certainly be useful to do more small-scale studies in different institutions and with different groups of students. Students with disabilities and second-language learners are particularly interesting populations, but it would also be interesting to look at more narrowly defined groups of students by major or year, or even within a single course.

This study only considers college students, a population whose needs are very likely different from those of the general population. It would also be interesting to do similar studies with other populations, especially populations of heavy readers.

The most important questions raised by this research concern the effectiveness of electronic textbooks and the usefulness of electronic texts in classes generally. The study participants expressed some skepticism toward them. These questions need to be studied carefully to resolve the potential conflict between the pro-digital atmosphere of higher education and the preferences and needs of students.

\section{Appendix. Diary Form}

Please answer these questions anytime you read for ten minutes or more.

Please enter your assigned number

Date (Date the reading was done)

[Specific dates removed for space considerations]

What time of day was it?

O Morning (7 a.m.-10 a.m.)

O Midday (10 a.m.-1 p.m.)

- Afternoon (1 p.m.-4 p.m.)

Evening (4 p.m.-7 p.m.)

O Night (7 p.m.-10 p.m.)

○ Late (After 10 p.m.)

\section{What did you read?}

Briefly describe the nature of the material. For instance: Internet article, journal article, novel, textbook, blog, etc. Be specific, but don't include the title.

\section{For what purpose did you read?}

For instance: to study for a test, to learn more about my favorite sports team, for pleasure.

\section{How much time did you spend reading?}

Please give an approximate answer in hours and minutes.

\section{Where were you physically located as you read?}

For instance: at home, in the library, on the bus, etc.

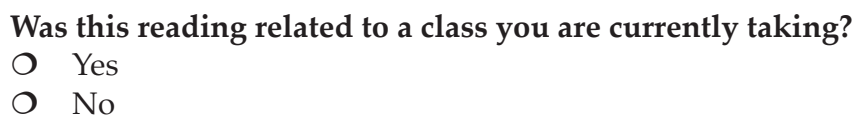




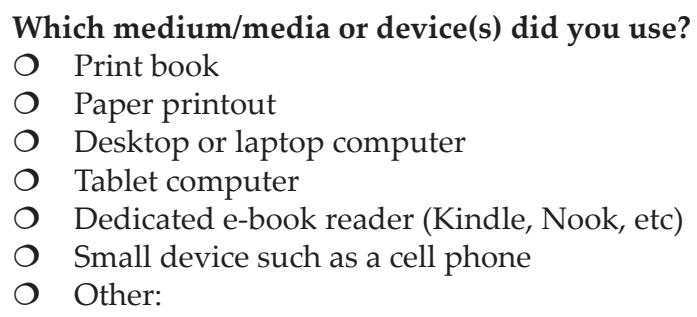

\section{How closely did you read?}

O Quickly scanned for the specific piece of information I needed

O Skimmed over the reading to get the main ideas

- Read carefully and sequentially

- Read nonsequentially, but engaged with the text in other ways

Please indicate any ways that you engaged with the text beyond simply reading it.

O Marked up the text by underlining, highlighting, etc.

- Took notes on a separate sheet of paper

O Used a reference text such as an encyclopedia or dictionary to look up words, references, or topics

O Followed links or citations included in the text

O Shared with someone else

O None

O Other:

\section{Notes}

1. Lee Rainie, Kathryn Zickuhr, Kristen Purcell, Mary Madden, and Joanna Brenner, "The Rise of E-Reading," Pew Research Center's Internet \& American Life Project (Washington, D.C., Apr. 4, 2012): 23, available online at http://libraries.pewinternet.org/2012/04/04/the-rise-of-e-reading/ [accessed 22 July 2014]; Wendy Allen Shelburne, "E-book Usage in an Academic Library: User Attitudes and Behaviors," Library Collections, Acquisitions \& Technical Services 33, no. 2/3 (2009): 55-59, doi: 10.1016/j.lcats.2009.04.002; Nancy M. Foasberg, "Adoption of E-book Readers among College Students: A Survey," Information Technology and Libraries 30, no. 3 (2011): 113, available online at ejournals.bc.edu/ojs/index.php/ital/article/view/1769 [accessed 22 July 2014]; Michael Levine-Clark, "Electronic Book Usage: A Survey at the University of Denver," portal: Libraries and the Academy 6, no. 3 (2003): 285-99; David Nicholas, Ian Rowlands, David Clark, Paul Huntington, Hamid R. Jamali, and Candela Ollé, "UK Scholarly E-Book Usage: A Landmark Survey," ASLIB Proceedings 60, no. 4 (2008): 311, doi:10.1108/00012530810887962. The final item does not specifically ask whether students use different formats, but they find that about 60 percent of their respondents use e-books, and 71 percent visit the library, primarily to browse and check out print books. Finally, the existence of studies on transliteracy, which describes "reading, writing and interacting across a range of platforms, tools, media and cultures," suggests that using multiple media to get information is a popular practice. Sue Thomas, Chris Joseph, Jess Laccetti, Bruce Mason, Simon Mills, Simon Perril, Kate Pullinger, "Transliteracy: Crossing Divides," First Monday 12, no. 12 (2007), available online at www.uic.edu/htbin/cgiwrap/bin/ojs/index.php/fm/ article/view/2060/1908 [accessed 22 July 2014].

2. Rainie, Zickuhr, Purcell, Madden, and Brenner, "The Rise of E-Reading."

3. Ibid., 39.

4. Foasberg, "Adoption of E-book Readers among College Students."

5. Aaron K. Shrimplin, Andy Revelle, Susan Hurst, and Kevin Messner, "Contradictions and Consensus-Clusters of Opinions on E-books," College and Research Libraries 72, no. 2 (2011): 181-90, available online at http://crl.acrl.org/content/72/2/181.abstract [accessed 22 July 2014].

6. Jacqueline Ann Chelin, Jason Briddon, Elspeth Williams, Jane Redman, Alastair Sleat, and Greg Ince, "'E-books Are Good If There Are No Copies Left': A Survey of E-book Usage at UWE Library Services," Library and Information Research 3, no. 104 (2009): 44-65, available online 
at www.lirgjournal.org.uk/lir/ojs/index.php/lir/article/view/114 [accessed 22 July 2014].

7. Sue Caporn, Lee Bryant, Karen Foster, and Emma Ransley, "Engaging Students with Ebooks in Further Education," in E-books in Libraries: A Practical Guide, ed. Kate Price and Virginia Havergal (London: Facet Publishing, 2011), 217-35.

8. Dominic Broadhurst and Janette Watson, "E-book Readers for Full-Time MBA Students: An Investigation in Manchester," Journal of Business \& Finance Librarianship 17, no. 2 (2012): 177, doi:10.1080/08963568.2012.660735.

9. Wendy Allen Shelburne, "E-book Usage in an Academic Library: User Attitudes and Behaviors," Library Collections, Acquisitions \& Technical Services 33, no. 2/3 (2009): 55-59, doi:10.1016/j. lcats.2009.04.002.

10. Catherine C. Marshall and Christine Ruotolo, "Reading-in-the-Small: A Study of Reading on Small Form Factor Devices," in Proceedings of the 2nd ACM/IEEE-CS Joint Conference on Digital Libraries (Portland, Ore.: Association for Computing Machinery, 2002), 59-60, doi:10.1145/544220.544230.

11. Chelin et al., "E-books Are Good If There Are No Copies Left," 56.

12. Kate Sandberg, "College Student Academic Online Reading: A Review of the Current Literature," Journal of College Reading and Learning 42, no. 1 (2011): 89-98.

13. Barry W. Cull, "Reading Revolutions: Online Digital Text and Implications for Reading in Academe," First Monday 16, no. 6 (2011), available online at http://journals.uic.edu/ojs/index. $\mathrm{php} / \mathrm{fm} /$ article/view/3340 [accessed 22 July 2014].

14. Selinda Adelle Berg, Kristin Hoffmann, and Diane Dawson, “Not on the Same Page: Undergraduates' Information Retrieval in Electronic and Print Books," Journal of Academic Librarianship 36, no. 6 (2010): 521, doi:10.1016/j.acalib.2010.08.008

15. Muhammad Asim Qayyum, "Capturing the Online Academic Reading Process," Information Processing and Management 44, no. 2 (2008): 591, doi:10.1016/j.ipm.2007.05.005.

16. Anne Worden and Timothy Collinson, "Engaging Staff and Students with E-books in a University Setting," in E-books in Libraries: A Practical Guide, eds. Kate Price and Virginia Havergal (London: Facet Publishing, 2011), 237-51.

17. William Douglas Woody, David B. Daniel, and Crystal A. Baker, "E-books or Textbooks: Students Prefer Textbooks," Computers \& Education 55, no. 3 (2010): 947, doi:10.1016/j.compedu.2010.04.005; Mitchell Weisberg, "Student Attitudes and Behaviors toward Digital Textbooks," Publishing Research Quarterly 27, no. 2 (2011): 188-96, doi:10.1007/s12109-011-9217-4; James A. Shepperd, Jodi L. Grace, and Erika J. Koch, "Evaluating the Electronic Textbook: Is It Time to Dispense with the Paper Text?" Teaching of Psychology 35, no. 1 (2008): 2-5, doi:10.1080/00986280701818532; Jessica Siebenbruner, "Electronic Versus Traditional Textbooks: A Comparison of College Textbook Formats," Journal on Excellence in College Teaching 22, no. 3 (2011): 75-92.

18. Siebenbruner, "Electronic Versus Traditional Textbooks," 88-89; Robert F. Vernon, "Paper or Pixels? An Inquiry into How Students Adapt to Online Textbooks," Journal of Social Work Education 42, no. 2 (2006): 422, doi:10.5175/JSWE.2006.200404104

19. Weisberg, "Student Attitudes and Behaviors toward Digital Textbooks."

20. Annette Adler, Anuj Gujar, Beverly L. Harrison, Kenton O'Hara, and Abigail Sellen, "A Diary Study of Work-Related Reading: Design Implications for Digital Devices," in Proceedings of the SIGCHI Conference on Human Factors in Computing Systems, 241-48 (Los Angeles, Calif.: Association for Computing Machinery, 1998), doi:10.1145/274644.274679; Shelburne, "E-book Usage in an Academic Library," 64.

21. Alexander Thayer, Charlotte P. Lee, Linda H. Hwang, Heidi Sales, Pausali Sen, and Ninad Dalal, "The Imposition and Superimposition of Digital Reading Technology: The Academic Potential of E-readers," in Proceedings of the SIGCHI Conference on Human Factors in Computing Systems (Vancouver, B.C.: Association for Computing Machinery, 2011). 2917-26, doi:10.1145/1978942.1979375.

22. Cynthia L. Gregory, “'But I Want a Real Book': An Investigation of Undergraduates' Usage and Attitudes toward Electronic Books," Reference \& User Services Quarterly 47, no. 3 (2008): 270, available online at http://rusa.metapress.com/content/p28u464t2116465n/ [accessed 22 July 2014].

23. Roman Tarbaran, Marcel Kerr, and Kimberly Rynearson, "Analytic and Pragmatic Factors in College Students' Metacognitive Reading Strategies," Reading Psychology 25, no. 2 (2004): 67-81, doi:10.1080/02702710490435547.

24. Weisberg, "Student Attitudes and Behaviors toward Digital Textbooks."

25. Alexandra Alter, "Your E-book Is Reading You," Wall Street Journal, June 29, 2012, available online at http://online.wsj.com/article/SB10001424052702304870304577490950051438304.html [accessed 22 July 2014].

26. David A. Joliffe and Allison Harl, "Studying the 'Reading Transition' from High School to College: What Are Our Students Reading and Why?" College English 70, no. 6 (2008): 599-617.

27. Kouider Mokhtari, Carla A. Reichard, and Anne Gardner, "The Impact of Internet and Television Use on the Reading Habits and Practices of College Students," Journal of Adolescent \& 
Adult Literacy 52, no. 7 (2009): 609-19, doi:10.1598/JAAL.52.7.6.

28. Julie Gilbert and Barbara Fister, "Reading, Risk and Reality: College Students and Reading for Pleasure," College and Research Libraries 72, no. 5 (2011): 483, available online at http://crl.acrl. org/content/72/5/474.abstract [accessed 22 July 2014].

29. Dan Berrett, "Students May Be Reading Plenty, But Not for Class," Chronicle of Higher Education, May 1, 2013, available online at http://chronicle.com/article/Students-May-Be-Reading/138911/ [accessed 22 July 2014].

30. Melanie Parlette and Vivian Howard, "Pleasure Reading among First-Year University Students," Evidence Based Library and Information Practice 5, no. 4 (2010): 60, available online at http://ejournals.library.ualberta.ca/index.php/EBLIP/article/view/8630 [accessed 22 July 2014].

31. Dale J. Cohen, Sheida White, and Steffaney B. Cohen, "A Time Use Diary Study of Adult Everyday Writing Behavior," Written Communication 28, no. 1 (2011): 3-33, doi:10.1177/0741088310381260; Jennifer L. Tomes, Louise Wasylkiw, and Brittany Mockler, "Studying for Success: Diaries of Students' Study Behaviors," Educational Research and Evaluation 17, no. 1 (2011): 1-12, doi:10.1080/13803611.2011.563087; Killian Mullan, "Families That Read: A Time-Diary Analysis of Young People's and Parents' Reading," Journal of Research in Reading 33, no. 4 (2010): 414-30, doi:10.1111/j.1467-9817.2010.01438.x.

32. Joliffe and Harl, "Studying the 'Reading Transition' from High School to College."

33. Craig S. Tashman and W. Keith Edwards, "Active Reading and Its Discontents: The Situations, Problems and Ideas of Readers," in Proceedings of the SIGCHI Conference on Human Factors in Computing Systems (Vancouver, B.C.: Association for Computing Machinery, 2011), 2927-36, doi:10.1145/1978942.1979376; Thayer et al., "The Imposition and Superimposition of Digital Reading Technology."

34. Mokhtari, Reichard, and Gardner, "The Impact of Internet and Television Use;" Berrett, "Students May Be Reading Plenty, But Not for Class."

35. Gilbert and Fister, "Reading, Risk and Reality;" Mokhtari, Reichard, and Gardner, "The Impact of Internet and Television Use."

36. Thayer et al., "The Imposition and Superimposition of Digital Reading Technology."

37. Jeff Blagdon, "Obama Administration Wants All Students Using Digital Textbooks in Five Years," The Verge, Feb. 3, 2012, available online at www.theverge.com/2012/2/3/2767593/ obama-administration-digital-textbooks-5-years [accessed 22 July 2014].

38. Mary Helen Miller, "California Law Encourages Digital Textbooks by 2020," Wired Campus, Chronicle of Higher Education, Jan. 14, 2010, available online at http://chronicle.com/blogs/wiredcampus/california-law-encourages-digital-textbooks-by-2020/20526 [accessed 22 July 2014]; Kate Taylor, "Quinn Presents Vision for Improving New York City Schools," New York Times, Jan. 16, 2013; Ben Wolfgang, "S. Korea Leads Way for Paperless Classroom; U.S. Lags with State Control Steps." Washington Times, July 19, 2011; Yasmeen Abutaleb, "Universities Push E-textbook Sales; Student Use Becomes a Course Requirement," USA Today, Aug. 14, 2012.

39. A good overview can be found here: Eleanor J. Goldberg and Michael LaMagna, "Open Educational Resources in Higher Education," College and Research Libraries News 73, no. 6 (2012): 334-37, available online at http://crln.acrl.org/content/73/6/334.full.pdf+html [accessed 22 July 2014]. Other articles cover specific efforts in this field: Eryn Jelesiewicz, "Temple Faculty Experiment with Alt-Textbooks," Temple University University Commnications, Jan. 27, 2012, available online at http://news.temple.edu/news/temple-faculty-experiment-alt-textbooks [accessed 22 July 2014]; Charles Huckabee, "Project in Washington State Creates Online Textbooks for 81 Courses," Ticker, Chronicle of Higher Education, May 1, 2013, available online at http://chronicle.com/blogs/ ticker/washington-state-project-completes-online-textbooks-for-81-courses/59473 [accessed 22 July 2014]; "Open Textbooks in California," U.S. Department of Education, n.d., available online at www.edgov/technology/draft-netp-2010/open-textbooks-california [accessed 22 July 2014]. "Open Education Resources," The Alternate Textbook Project, Temple University's website, n.d., available online at http://sites.temple.edu/alttextbook/open-education-resources/ [accessed 22 July 2014] provides a good list of resources.

40. "Open Textbook Catalog," Open Academics, University of Minnesota's website, available online at https://open.umn.edu/opentextbooks/ [last modified 4 January 2012]. 